\title{
Adult Pituitary Stem Cells: From Pituitary Plasticity to Adenoma Development
}

\author{
Tullio Florio \\ Laboratory of Pharmacology, Department of Oncology, Biology and Genetics, and Center of Excellence for \\ Biomedical Research, University of Genoa, Genoa, Italy
}

\section{Key Words}

Pituitary · Stem cells · Progenitor cells · Side population • Sox $2 \cdot$ Nestin $\cdot$ Cancer stem cells $\cdot$ Pituitary adenoma

\begin{abstract}
The pituitary needs high plasticity of the hormone-producing cell compartment to generate the continuously changing hormonal signals that govern the key physiological processes it is involved in, as well as homeostatic cell turnover. However, the underlying mechanisms are still poorly understood. It was proposed that adult stem cells direct the generation of newborn cells with a hormonal phenotype according to the physiological requirements. However, only in recent years adult pituitary stem cells have begun to be phenotypically characterized in several studies that identified multiple stem/progenitor cell candidates. Also considering the incompletely defined features of this cell subpopulation, some discrepancies among the different reports are clearly apparent and long-term self-renewal remains to be unequivocally demonstrated. Here, all the recently published evidence is analyzed, trying, when possible, to reconcile the results of the different studies. Finally, with the perspective of shedding light on pituitary tumorigenesis and the development of potentially new pharmacological approaches directed against these cells, very recent evidence on the presence of putative cancer stem cells in human pituitary adenomas is discussed.

Copyright $\odot 2011$ S. Karger AG, Basel
\end{abstract}

\section{Introduction}

A fine tuning of pituitary functioning is required to properly regulate body homeostasis, growth and reproduction. Hypothalamic neuroendocrine control and highly synchronized feedback mechanisms are able to modulate pituitary hormone secretion, adjusting their levels to functional or environmental requirements. Nevertheless, in several physiological conditions (growth, puberty, pregnancy, and lactation) functional changes in hormone secretion rate are not sufficient to fulfill the request of the organism and a general reorganization of pituitary structure and cell composition may occur. Steadystate pituitary cell turnover is generally extremely low, as it has been estimated that, at basal mitotic pituitary rate, up to 10 weeks are required to replace the constituent cells $[1,2]$. However, it is well known that after adrenalectomy or orchiectomy the number of cortico- or gonadotrope cells largely increase in the adult pituitary due to the differentiation of hormonally null cells formed by a previous large wave of mitosis $[3,4]$. Moreover, the same pool of cells was shown to expand in these experimental models, clearly supporting the notion of the presence of a progenitor cell population responsible for these responses [5]. Furthermore, in a more physiological setting, lactotrope number increases by several fold during pregnancy and lactation to adapt the prolactin secretion required under those conditions [6].

\section{KARGER}

Fax +4161306 1234

E-Mail karger@karger.ch

www.karger.com (c) $2011 \mathrm{~S}$. Karger AG, Basel

0028-3835/11/0944-0265\$38.00/0

Accessible online at:

www.karger.com/nen
Tullio Florio, $\mathrm{MD}, \mathrm{PhD}$

Laboratory of Pharmacology, Department of Oncology, Biology and Genetics and Center of Excellence for Biomedical Research

University of Genoa, Viale Benedetto XV, 2, IT-16132 Genoa (Italy)

Tel. +39010 353 8806, E-Mail tullio.florio@unige.it 
Three possible mechanisms have been proposed to justify this evidence: (1) differentiated (hormone-producing) cells enter mitosis [7]; (2) transdifferentiation from a preexisting cell population [8], and (3) recruitment of putative adult pituitary stem/progenitor cells [9].

Some experimental data seem to exclude a primary role for the first two mechanisms, mitotic activation of differentiated/hormone-producing pituitary cells and transdifferentiation from a different pituitary cell type (classically, the conversion of somatotropes to lactotropes). In fact, mitotic events observed during adrenalectomy mainly involve hormonally null cells (>90\%) that only after few weeks differentiate into corticotropes [for review see, 10,11]. Similarly, genetic lineage trace experiments suggested that new prolactin-secreting cells, developed in response to estrogens (for example during pregnancy), are rarely derived from differentiated somatotrope cells [12], but are mainly derived from a self-limiting wave of proliferation of the non-hormonal pool of pituitary cells [6]. All this evidence led to the hypothesis that both basal pituitary cell turnover and cellular changes occurring as dynamic adaptation in physiological or pathological conditions could be driven by the recruitment of a still unidentified, small pituitary cell subpopulation endowed with stem/progenitor cell characteristics [9].

In the past, a large effort was dedicated to the search for putative stem cell populations within the pituitary gland. However, although several different candidates have been identified in studies mainly involving murine models, a definitive conclusion about this issue has not been reached so far.

\section{Normal Stem Cells}

Cell populations with stem-like properties have been identified and characterized in several adult tissues. Stem cells have been recognized as undifferentiated cells able to divide indefinitely (self-renewal), generating either two daughter stem cells or, through the asymmetric division process, giving origin, on the one hand, to a daughter cell endowed with equal developmental and biological properties of the original stem cell, and, on the other hand, to a progenitor cell. Progenitors have more restricted potential, undergoing to a limited number of cell divisions and maintaining the capability of differentiating only into cell types of the specific tissue of origin [13].

Self-renewal, together with the capacity to differentiate into multiple lineages and constantly proliferate, rep- resents one of the main defining features of stem cells [14].

Normal stem cells have been identified at embryonic stages as totipotent cells able to generate all cell types that constitute developed tissues, while in adult organs these cells are more specialized 'adult or somatic stem cells', continuously providing differentiated cells to their specific tissue compartment. Adult stem cells are involved in tissue maintenance and repair and have been detected both in organs with high cell turnover rate, such as bone marrow, colon and skin, and in organs with lower cell turnover, such as breast, lung, and brain. The long lifespan of normal stem cells is believed to depend on specific biological properties such as relative quiescence, active DNA-repair capacity, resistance to apoptosis and the over-expression of several ATP-binding cassette transporters, leading to resistance not only to toxins but also to a wide range of drugs [15].

In mammals, normal stem cells reside in specific areas of each tissue named 'niches' that support stem cell survival and anchor them in the appropriate microenvironment [16]. Adult stem cell niches differ in their cellular composition, structure and location in different tissues. To date, these areas have been identified in bone marrow, brain, skin, intestine and testis, but it was hypothesized that all the organs and tissues may contain niches homing stem cell populations required for tissue homeostasis. The interaction of stem cells with specific niches is critical for maintaining their biological properties and, in particular, for the balance between self-renewal and differentiation which plays a pivotal role in both cell number regulation and tissue maintenance [17].

Stem cell subpopulation sustains adult tissue homeostasis granting cell replacement during the aging process or after damage. The self-renewal property of stem cells allows the persistence of a constant number of these cells in the niches of a given organ. In response to specific stimuli, not completely characterized yet, stem cells enter asymmetric division, yielding a stem cell and a daughter cell committed to differentiation (progenitor). Progenitors display limited self-renewal activity but have a higher proliferation rate generating a transit-amplifying cell population that, according to the specific microenvironment where they grow, terminally differentiates into the specialized cells composing each organ. In this model, the term 'stem cell' is restricted to cells characterized by both unlimited self-renewal capacity and the potential to give rise to differentiated progeny [18]. 
Table 1. Comparison of the main characteristics of the proposed pituitary stem/progenitor cells

\begin{tabular}{|c|c|c|c|c|c|}
\hline & $\begin{array}{l}\text { Side population } \\
\text { (non-Sca }^{\text {high }} \text { ) }\end{array}$ & Colony-forming cells & $\begin{array}{l}\text { Nestin-expressing } \\
\text { cells }\end{array}$ & Sox $2^{+} /$Sox $9^{-}$cells & GPS cells \\
\hline $\begin{array}{l}\text { Expression in AP } \\
\text { (\% of total cells) }\end{array}$ & $\begin{array}{l}40 \% \text { of side population } \\
\text { (SP: } 1.5 \% \text { of AP cells) }\end{array}$ & $\begin{array}{l}0.2 \% \text { of AP cells } \\
(12 \% \text { of FS cells })\end{array}$ & $\begin{array}{l}2 \% \text { of AP cells (at birth), } \\
\text { up to } 20 \% \text { ( } 5 \text {-month-old } \\
\text { mice)* }\end{array}$ & $3-5 \%$ of AP cells & $0.9 \%$ of AP cells \\
\hline Location in AP & $\begin{array}{l}\text { Marginal zone lining the } \\
\text { cleft (scattered in AP) }\end{array}$ & $\begin{array}{l}\text { Consistent with FS cell } \\
\text { distribution } \\
\text { (as for FS markers) }\end{array}$ & $\begin{array}{l}\text { Distributed in AP } \\
\text { (often in pericyte location } \\
\text { lining the cleft) }\end{array}$ & $\begin{array}{l}\text { Marginal zone lining } \\
\text { the cleft (scattered in } \\
\text { AP) }\end{array}$ & $\begin{array}{l}\text { Marginal zone, lining the } \\
\text { cleft (scattered in AP) }\end{array}$ \\
\hline $\begin{array}{l}\text { Short-term } \\
\text { spherogenesis }\end{array}$ & +++ & $+++($ Colonies $)$ & $\begin{array}{l}\text { (Colonies, in human cell } \\
\text { studies) }\end{array}$ & +++ & +++ \\
\hline $\begin{array}{l}\text { Stem cell } \\
\text { phenotype }\end{array}$ & $\begin{array}{l}\text { Sca1 (low) } \\
\text { Nestin, Sox2, PROP1 } \\
\text { E-cadherin, LHX3 }\end{array}$ & $\begin{array}{l}\text { S100 } \\
\text { GFAP } \\
\text { Sca1 }(40 \%)\end{array}$ & Nestin, Sox2, LHX3 & $\begin{array}{l}\text { Sox } 2^{+} / \text {Sox } 9^{-} \text {Sca }^{+} \\
\text {E-cadherin }\end{array}$ & $\begin{array}{l}\text { GFRa2, Sox } 2 \text {, Sox } 9 \text {, } \\
\text { E-cadherin, } \beta \text {-catenin, } \\
\text { OCT-4, PROP1; S100 (50\%) }\end{array}$ \\
\hline $\begin{array}{l}\text { Differentiation } \\
\text { phenotype }\end{array}$ & Sox2 (neg) & & Pit1 (small, \%) & $\begin{array}{l}\text { Sox } 2^{+} / \text {Sox } 9^{+} \text {S } 100^{+} \\
\text {E-cadherin }\end{array}$ & $\begin{array}{l}\beta \text {-III-tubulin }{ }^{+} \\
\text {GFRa2 }^{-}, \mathrm{OCT}_{-} 4^{-}, \mathrm{PROP}^{-}\end{array}$ \\
\hline $\begin{array}{l}\text { Pituitary hormone } \\
\text { expression (after } \\
\text { differentiation) }\end{array}$ & All pituitary hormones & $\begin{array}{l}\mathrm{GH}(3 \% \text { of the } \\
\text { population) }\end{array}$ & $\begin{array}{l}\text { All pituitary hormones } \\
\text { (PRL only, in human cell } \\
\text { studies) }\end{array}$ & $\begin{array}{l}\text { All pituitary } \\
\text { hormones }\end{array}$ & $\begin{array}{l}\text { All pituitary hormones } \\
\text { (using a specific medium } \\
\text { for each hormone) }\end{array}$ \\
\hline Notes & $\begin{array}{l}\text { Mixed stem/transit } \\
\text { amplifying populations, } \\
\text { as for the differential } \\
\text { expression of Sox2 (50\%) } \\
\text { and Sox9 }(30 \%)\end{array}$ & $\begin{array}{l}\text { Characterized by uptake } \\
\text { of the fluorescent } \\
\text { dipeptide } \beta \text {-Ala-Lys- } \\
\mathrm{N} \varepsilon \text {-AMCA }\end{array}$ & $\begin{array}{l}{ }^{*} \text { Evaluated as GFP } \\
\text { expression in nestin-cre } \\
\text { Tg mice }\end{array}$ & $\begin{array}{l}\text { Sox } 9^{+} \text {cells are highly } \\
\text { proliferating and } \\
\text { believed to be transit } \\
\text { amplifying cells }\end{array}$ & $\begin{array}{l}\text { They likely represent transit } \\
\text { amplifying cells, } \\
\text { corresponding to Sox } 9^{+} \text {cells }\end{array}$ \\
\hline References & {$[22,25]$} & {$[30,31]$} & {$[35,36]$} & {$[26]$} & [37] \\
\hline
\end{tabular}

\section{Stem Cells in Adult Pituitary}

In the past, several cell populations with stem cell-like properties have been identified and characterized in the adult pituitary, although most studies were performed in murine models. The various studies published reported the identification of different cell phenotypes that are only partially reconcilable. However, further studies using a more standardized experimental setting are still required to obtain a more unique definition of pituitary stem cells.

The more relevant studies in the field are described below, while a comparison of the different features of the proposed pituitary stem cell populations is reported in table 1.

\section{Side Population}

As previously outlined, there is much evidence to support the presence of stem cells in the adult pituitary, but only in recent years have more convincing data been produced to sustain this hypothesis, opening a completely novel and rapidly growing field of research. In fact, the definitive demonstration of pituitary stem cells may have significant clinical impact, for example, in adult onset hypopituitarism in the context of regenerative medicine [19], as proposed for pancreatic $\beta$-cells in type 1 diabetes or, more importantly, for pituitary tumors in light of the cancer stem cell theory of tumor development, as discussed in the following paragraphs.

One of the first stem-like cell features that was used to identify this subpopulation in the mouse pituitary was the activity of $\mathrm{ABC}$ transporters. These molecules are able to extrude from the cytosol potential toxicants (including cytotoxic drugs) and are over-expressed in stem cells. In fact, due to their long lifespan that exposes them to a high number of environmental injuries, stem cells develope extremely efficient defensive systems, including DNA repair mechanisms and extruding pumps [20]. It was reported that about $1.5 \%$ of mouse anterior pituitary cells efficiently excluded a fluorescent dye (Hoechst 33342), showing an activity reminiscent of stem cells. Biochemical analysis of this 'side population' (SP; as for the FACS analysis appear- 
ance) demonstrated the over-expression of several stem cell-associated markers (nestin, Sca1, Nanog, CD133, Oct4) and molecular effectors of self-renewal (Notch, Wnt, Shh) [21, 22], although a small part of SP (5.8\%) showed FS phenotype [22]. Conversely, all these markers were not (or minimally) expressed in the other pituitary cells (main population) [22].

Moreover, SP cells are able to clonally grow as nonadherent spheres (pituispheres) [22], a feature that, when retained after serial passages, is recognized as self-renewal activity and shared by stem/progenitor cells of multiple tissues $[23,24]$. About $0.02 \%$ of the seeded anterior pituitary cells generated spheres that were characterized as cells expressing Oct-4, CD133 and components of the Notch, Wnt and Shh pathways, while pituitary hormones were not detected. This pattern of expression represents a molecular picture largely shared by SP cells in several tissues [22].

A more detailed analysis of SP allowed the identification of two distinct subpopulations, according to the level of expression of the stem cell marker Sca1. Expression profiling using whole genome microarray and qRT-PCR suggested that the putative adult pituitary progenitors may be the SP not expressing high levels of Scal (nonSca $1^{\text {high }}$ fraction; about $40 \%$ of the total SP) being, different from the Sca $1^{\text {high }}$ population, spherogenic (at least for a limited number of passages) and able to differentiate in the endocrine cell types present in pituitary. These cells over-express, as compared to the Scal ${ }^{\text {high }}$ fraction, several transcription factors detected during pituitary development (Hesx1, Prop1, Pax6, Lhx4), components of MAP kinase, Wnt, and Notch pathways, and inhibitors of apoptosis [25]. The Notch pathway, known to control stem cells in undifferentiated status [19], was demonstrated to play an important role in the proliferation of these cells, being modulated by the growth factors commonly used to select stem cells in vitro (EGF, bFGF and LIF) [25]. Sox 2 and Sox 9 were also detected in non-Scal ${ }^{\text {high }}$ cells (about 50 and $30 \%$ of this subpopulation, respectively), while nestin was equally detected in non-Scal ${ }^{\text {high }}$ and Scal ${ }^{\text {high }}$ cells. These latter data are in agreement with the observation that nestin is expressed in several nonendocrine pituitary cells, including folliculo-stellate (FS) cells (representing a component of Sca $1^{\text {high }}$ subset) and pericytes. However, in pituispheres derived from nonScal ${ }^{\text {high }}$ cells, nestin was co-localized with Sox2 [26]. Since the Scal ${ }^{\text {high }}$ cell population expresses $S-100 \beta$ and several angiogenesis-related genes, it was proposed that these cells may represent a subset of FS cells and/or endothelial progenitors rather than pituitary progenitors [25].

\section{Pituitary Colony-Forming Cells}

In these studies, a colony-forming assay was used to identify stem/progenitor cells from the adult pituitary, as already performed in other tissues. Pituitary cells that in vitro can clonally expand as colonies were isolated from Rathke's pouch several years ago. Not unexpectedly, some of these embryonic clones were found to be multipotent and to give rise to all AP hormonal cell types, in vitro as well as in vivo, after transplantation under the hypothalamus of hypophysectomized rats [27, 28]. In recent years, it was observed that pituitary colony-forming cells belong to the FS compartment according to the uptake of the fluorescent dipeptide $\beta$-Ala-Lys-N $\varepsilon$-AMCA, a functional property of FS cells [29]. It was shown that about $12 \%$ of mouse pituitary FS cells (characterized phenotypically as $\mathrm{S}-100^{+}$and $\mathrm{GFAP}^{+}$, and, in about $40 \%$ of the cells, Scal) were clonogenic and that, within the colonies formed from these cells, some $\mathrm{GH}$ - or prolactin-expressing cells were generated, suggesting a differentiation of putative progenitor cells [30]. Using a more sophisticated in vivo approach, the differentiation of a small proportion (3.3\%) of the colony-forming FS cells into GH-expressing cells was observed [31]. More recently, it was observed that the FS cell marker S-100 $\beta$ was co-expressed by $80 \%$ of the pituitary cells that also express Sox2, proposed as pituitary stem cell marker (see below), and that in vitro, cultured in the presence of retinoic acid and bFGF, a limited number of them differentiate into Pit1-expressing or GHsecreting cells [32]. These studies thus provided evidence that several FS subpopulations exist, including one endowed with pituitary progenitor cell properties [31]. Conversely, other cells within this population may overlap with the Scal ${ }^{\text {high }}$ SP, at least for marker expression (S-100, Sca1) [25]. Importantly, in situ these clonogenic cells were mainly localized in the marginal zone of the pituitary cleft (the marginal zone between intermediate and anterior lobes), the proposed pituitary stem cell niche [33]. Thus, it was concluded that some cells of the postnatal pituitary exhibit the stem cell-associated feature of expansion as adherent colonies in vitro. However, given the limited differentiation capacity observed (only toward somatotropes), these cells may represent already committed progenitor cells.

\section{Nestin-Expressing Cells}

As for studies in other tissues, evidence of putative stem cells in the pituitary derived from the identification of stem markers in cell subpopulations of adult tissues. In particular, in the rat pituitary, several nestin-expressing cells were identified all over the gland [34]. However, a 
specific location for these cells was lining the cleft, the possible pituitary stem cell niche [9]. Importantly, these cells show neither hormone-secreting nor FS features [34]. Cell cultures enriched in this population were established and the nestin-expressing cells showed mainly a characteristic mesenchymal phenotype. Using a transgenic approach, it was shown that nestin-GFP-positive cells could be detected in Rathke's pouch in mouse embryos, with fluorescence that involved a higher number of cells in the postnatal pituitary, mainly localized in the proximity of the cleft and showing Sox 2 expression [35]. Cell lineage studies were performed using nestin-Cre mice, in which the progeny of nestin-expressing cells are permanently GFP-positive. These studies demonstrated that about $2 \%$ of fluorescent cells are detected in the pituitary of newborn mice, but this percentage rose up to $20 \%$ in adults [35]. Importantly, nestin-expressing cells can differentiate in all adult pituitary endocrine cell types, although only a small percentage of them actually express Pitl. This observation suggests that this subpopulation may be composed by heterogeneous cell types, of which a small number could represent putative pituitary progenitors. However, the discrepancy between the low percentage of nestin-positive cells in embryos and the high percentage of positive cells among the adult endocrine cells allows to hypothesize that adult pituitary stem cells may constitute a different pool from embryonic progenitors. This hypothesis was supported also by evidence that nestin ${ }^{+}$is derived from differentiation of Sox $2^{+}$embryonic progenitors [26], thus likely representing a 'transient amplifying' population from which endocrine cells may derive. Nestin-GFP cells in vitro were reported to be clonogenic and in differentiation conditions of culture (in the presence of serum or a high concentration of cAMP induced by forskolin treatment) initially express nestin and Sox 2 but with time spontaneously differentiate in all pituitary endocrine cells [35].

More recently, a similar observation was made in human pituitaries from autopsies. Nestin-expressing cells were identified only in the perivascular space of pituitary capillaries. These cells were not labeled with antibodies identifying hormone-secreting, folliculo-stellate, or endothelial cells (in agreement with studies in the rat and mouse pituitary $[34,35])$, but co-expressed smooth muscle actin (SMA), suggesting a possible pericytic differentiation. Growing these cells on a fibroblast feeder layer the existence of two populations was demonstrated, of which one was characterized as differentiated pericytes $\left(\right.$ nestin $^{+}$and $\mathrm{SMA}^{+}$) and the second (only nestin ${ }^{+}$), accordingly to its self-renewal (spherogenesis) and differen- tiative potential (induction of prolactin expression in the presence of high cAMP levels) was proposed as human pituitary progenitor cells [36]. However, since a direct derivation of colonies from nestin ${ }^{+}$human cells was not demonstrated and long-term self-renewal not evaluated, further studies are required to obtain definitive data.

Although after clonogenic in vitro growth, nestinGFP cells did not show Scal expression, nestin expression was identified in non-Scal ${ }^{\text {high }}$ SP [25]. This discrepancy may depend on the different timing of analysis (soon after explant for the SP study, or after in vitro culture as in the nestin-GFP experiments), suggesting that progenitors may express multiple markers but at different development stages. Conversely, nestin was not detected in GPS cells (see below) [37].

Noteworthy, the possibility that ectopic expression of the nestin transgene may occur in a set of cells within Rathke's pouch was reported [38]. Ectopic activity in the embryonic gland, as observed with the nestin-GFP transgene in Rathke's pouch progenitors, would give rise to significant staining of postnatal AP cells that may not reflect the actual expression level in adult pituitary. Since nestin ${ }^{+}$cells mainly divide after birth, the authors proposed that these cells may represent quiescent progenitors necessary for the initial wave of pituitary cell proliferation after birth and to maintain pituitary function in adults, and not the cells responsible for embryonic pituitary development. To identify nestin-expressing cells as stem cells, exclusive co-localization of Cre and nestin would been required [38].

It is likely that nestin is expressed by different cell populations during pituitary development and in adulthood, all labeled by nestin-GFP including both putative stem/ progenitor cells $\left(\mathrm{Sox}_{2}{ }^{+}\right.$and $\mathrm{LHX}^{+}$) and supportive cells or vascular progenitors. In this line, it is remarkable that nestin was expressed in both pituitary cells populations classified as non-Scal ${ }^{\text {high }}$ (likely pituitary progenitors) and Scal ${ }^{\text {high }}$ (likely vascular-endothelial progenitors) [25].

Thus, to date no coherent evidence was provided by the different studies on nestin ${ }^{+}$putative pituitary stem/ progenitor cell origin, and further studies are required to definitely establish their potential role in pituitary development.

\section{Sox $2^{+} /$Sox $9^{-}$Cells}

High Sox 2 expression, essential for CNS development, occurs in the embryo [39], while it is downregulated during cell differentiation and only adult stem cells retain Sox 2 expression. Importantly, it was demonstrated that 
Sox 2 is also required for normal pituitary development [40]. Using murine postnatal pituitary analysis, a pattern of Sox 2 expression similar to that of the developing embryonic gland was shown. Sox 2 was localized in about $3 \%$ of the postnatal anterior pituitary cells, mainly localized in the cell population lining the cleft but also scattered through the adenohypophysis $[25,26]$. These cells also often express E-cadherin, suggesting that epithelial to mesenchymal transition might be required for Sox 2-expressing cells to rapidly divide and differentiate [26]. In the adult, only $1 \%$ of the Sox $2^{+}$cells do not express Sox9, another transcription factor involved in embryo development for sex determination and later for chondrogenesis $[41,42]$. Sox9 is also involved in pituitary development but its expression in Rathke's pouch occurs much later than Sox2. Similar, although quantitatively different, results were obtained in the 'side population' studies [25] (see above), since most non-Scal ${ }^{\text {high }}$ cells express Sox2, while a lower percentage was reported to be Sox9-positive [26]. Importantly, by BrdU labelling, it was shown that, while Sox $2^{+} / \mathrm{Sox}^{+}{ }^{+}$cells are able to proliferate, although infrequently, Sox $2^{+} / \operatorname{Sox}^{-}$showed persistence of the staining in label-retaining experiments [26] indicating limited cell division activity. This observation suggests that, in adult pituitaries, Sox $2^{+}$cells may represent a quiescent multipotent cell subpopulation for organ maintenance [43]. Pituispheres generated in vitro by potential postnatal murine pituitary stem cells using selective culture conditions (medium containing growth factors without fetal calf serum, FCS) were characterized by Sox $2^{+} /$Sox $9^{-}$phenotype, while Sox 9 appeared only after 1 week in culture [26]. The analysis of Sox $2^{+}$cells, isolated by FACS using pituitaries derived from Sox2-EGFP mice [44], confirmed that Sox 2 expression was required for the sphere formation that originated only from GFPpositive cells [11]. However, these spheres could be propagated for only two passages, indicating that the Sox $2^{+}$ cells may be multipotent progenitors rather than real stem cells, for which at least 5 in vitro passages are considered a defining requirement [9]. Again, in agreement with SP studies [25], Sox2-positive cells within pituispheres also express E-cadherin and are completely hormone-negative [26]. However, Scal expression was reported [26], an observation discordant with the features identified in the proposed stem/progenitor cells within SP (non-Scal ${ }^{\text {high }}$ phenotype) [25].

Prolonged (1 week) in vitro culture allowed the expression of Sox9, nestin and S-100 in these cells, while Scal is downregulated, but no spontaneous differentiation occurred. The shift to a medium containing FCS, as report- ed for several stem cell cultures, caused the disaggregation of spheres and the adherence of the cells to the substrate inducing a FS-like phenotype [26]. Conversely, endocrine differentiation was not observed when culturing the cells in the presence of FCS, but, on the other hand, could be obtained while culturing cells without growth factors, as cellular aggregates on Matrigel. In these latter experimental conditions all the endocrine pituitary markers were detected in the cultures with, sometimes, the presence of multiple hormones in the same sphere, suggesting multipotentiality. From these observations, Sox $2 / E$-cadherin-positive, Sox $9 / \mathrm{S}$-100-negative cells were proposed as putative pituitary stem/progenitor cells, while Sox 2/Sox9/S-100-positive, E-cadherin-negative cells could represent a subpopulation of FS cells with transit amplifying properties, committed to differentiation [11].

\section{GPS Cells (GFR $\alpha 2-P R O P 1-S t e m$ Cell}

\section{Marker-Expressing Cells)}

A potential stem cell population within the adult rat pituitary was identified based on the expression of GFR $\alpha 2$, the GDNF co-receptor (altogether with the tyrosine kinase receptor Ret) [37].

As for most of the proposed putative adult pituitary stem cells, GFR $\alpha 2$-positive cells were mainly localized lining the cleft and only occasionally scattered through the anterior pituitary, representing about $0.9 \%$ of the pituitary cells [37]. These cells also express E-cadherin, $\beta$ catenin and the stem cell markers OCT4 and SSEA4, almost all (about 90\%) express Sox 2 and Sox 9 and about half of them were S-100-positive. On the contrary nestin was not detected, at odds with other studies $[25,34,35]$. PROP1, a transcription factor required to induce pituitary cell precursors to differentiate into Pit1-positive cells [45], was also detected in these cells. In embryos, Sox 2 co-localizes with PROP1 (but not with Pit1), while about $10 \%$ of the cells express both PROP1 and Pit1. In adults, differentiation commitment makes hormone-expressing cells retain Pit1 but not PROP1 [46].

This complex phenotype (expression of Sox 9 and S-100, co-localization of GFR $\alpha 2$ and PROP1) allowed the hypothesis that GPS cells may likely represent transit amplifying cells committed to differentiation rather than multipotent stem cells [11], very similar to the Sox $2^{+}$/ Sox $9^{+}$described by Fauquier et al. [26], which also retained the short-term ability to form spheres. A putative GPS cell niche was also identified both in rodents and humans in the periluminal zone, in which GPS cells are organized in an oriented manner, as a single cell layer 
bordering the cleft [37]. Interestingly, GFR $\alpha 2$ ligand neurturin is expressed in the anterior pituitary but not in the putative niche, suggesting that the secretion of this growth factor may regulate the activity of the GPS cells and their directional migration from the niche toward the pituitary parenchyma [37]. GPS cells isolated by FACS sorting give rise to spheroids in the absence of FCS but also without the commonly used stem cell-selective growth factors (EGF and bFGF), while neurturin increased sphere-forming efficiency, also displaying trophic effects [37]. These pituispheres express OCT4, Ecadherin and PROP1 and, when dissociated, can differentiate into all pituitary hormone- and/or $\beta$-III-tubulin (a neuronal marker)-expressing cells, growing as a monolayer onto collagen IV or poly-L-lysine-coated wells. The expression of the different hormones, however, required incubation in specific media, each one able to induce the expression of one pituitary hormone. The differentiation resulted in downregulation of GFR $\alpha 2$, OCT- 4 and PROP1 expression and the arrest of cell duplication [37].

\section{Cancer Stem Cells}

The stem cell model for the regulation of development/plasticity in adult tissues provided a new boost to study the tumorigenesis of several tissues.

Since stem cell fate is under strict control from both intrinsic (gene mutations) and extrinsic factors (microenvironment alterations), the loss of this control has been postulated to be a key step in the carcinogenic process. All tumors exhibit a heterogeneous cell type patterning, classified as a large number of 'tumor non-initiating cells' (or 'differentiated tumor cells'), which constitute the bulk of tumor mass, and a small fraction of phenotypically distinct 'tumor-initiating cells', representing the socalled 'cancer stem cells' (CSCs). Similarly to what is observed in normal tissues, different cell populations can be identified in tumors: slowly dividing stem cells (CSCs), precursor cells (rapidly dividing) transit amplifying cells and differentiated cells, the latter forming the organized tissue structure [47]. Thus, it was proposed that genetic and epigenetic alterations in normal cells may give rise to tumorigenic CSCs from which all the other 'differentiated' tumor cells originate.

CSCs derive their name by the ability to develop tumors (the same way by which normal stem cells are responsible of organ development) and not necessarily because they represent the malignant transformation of stem cells. In fact, there is still a large debate concerning

Adult Pituitary Stem Cells: From Pituitary

Plasticity to Adenoma Development the issue of the origin of CSCs. While some authors propose that CSCs actually derive from normal stem cells, other evidence supports the theory of a redifferentiation/ dedifferentiation from progenitor or differentiated cells, and a current hypothesis supports the involvement of both mechanisms in the origin of CSCs [48]. This hypothesis was proposed in light of the evidence that some cancers could originate from either transformed progenitors or normal progenitors that can re-acquire stem celllike behavior in response to specific transduction signals or mutations $[49,50]$. Thus, CSCs may arise from normal stem or progenitor cells by mutations in specific protooncogenes that, as a result of accumulative oncogenic events, may grant the self-renewal ability and fully transform normal cells into CSCs. Other evidence proposes that cancer growth and progression may also derive from modification of the microenvironment surrounding the stem cells, leading to loss of extrinsic control of normal stem cells or progenitors and the development of CSCs. Several genes and intracellular signaling pathways, involved in embryonic and normal stem cell control of proliferation, are deregulated in cancer, including components of self-renewal and proliferation pathways (Notch1, Hedgedog, Wnt, Sox2, Nestin) [51, 52].

Recent studies have begun to shed light on this issue, focusing on pituitary tumor development. First, it was reported that mice bearing mutations affecting $\beta$-catenin proteolysis in the pituitary and leading to constitutive activation of the $\mathrm{WNT} / \beta$-catenin pathway (obtained by crossing a Hesx 1 -cre knock-in strain to a $\beta$-catenin strain that produces degradation-resistant $\beta$-catenin mutant, upon recombination), developed tumors resembling, as far as histological appearance and marker expression are concerned, human adamantinomatous craniopharyngiomas [53]. Importantly, these authors demonstrated that increased tumorigenesis was associated with the expression of the mutant gene in putative pituitary progenitor/ stem cells (identified as Sox $2^{+}$, colony-forming cells) that resulted threefold increased in number and with higher proliferative activity than in the $w t$ counterpart. Importantly, the clongenic activity of the cells from Tg mouse pituitaries was long lasting (at least 8 passages) [53], clearly indicating a self-renewal activity [9]. Conversely, the expression of the same degradation-resistant form of $\beta$ catenin in differentiated pituitary cells was not tumorigenic [53]. Accordingly, it was reported that a novel mutation in SOX2 gene, which was proposed as putative pituitary stem/progenitor cell marker, did not impair transactivation or DNA-binding, but failed to repress $\beta$ catenin-mediated target activation, resulting in increased 


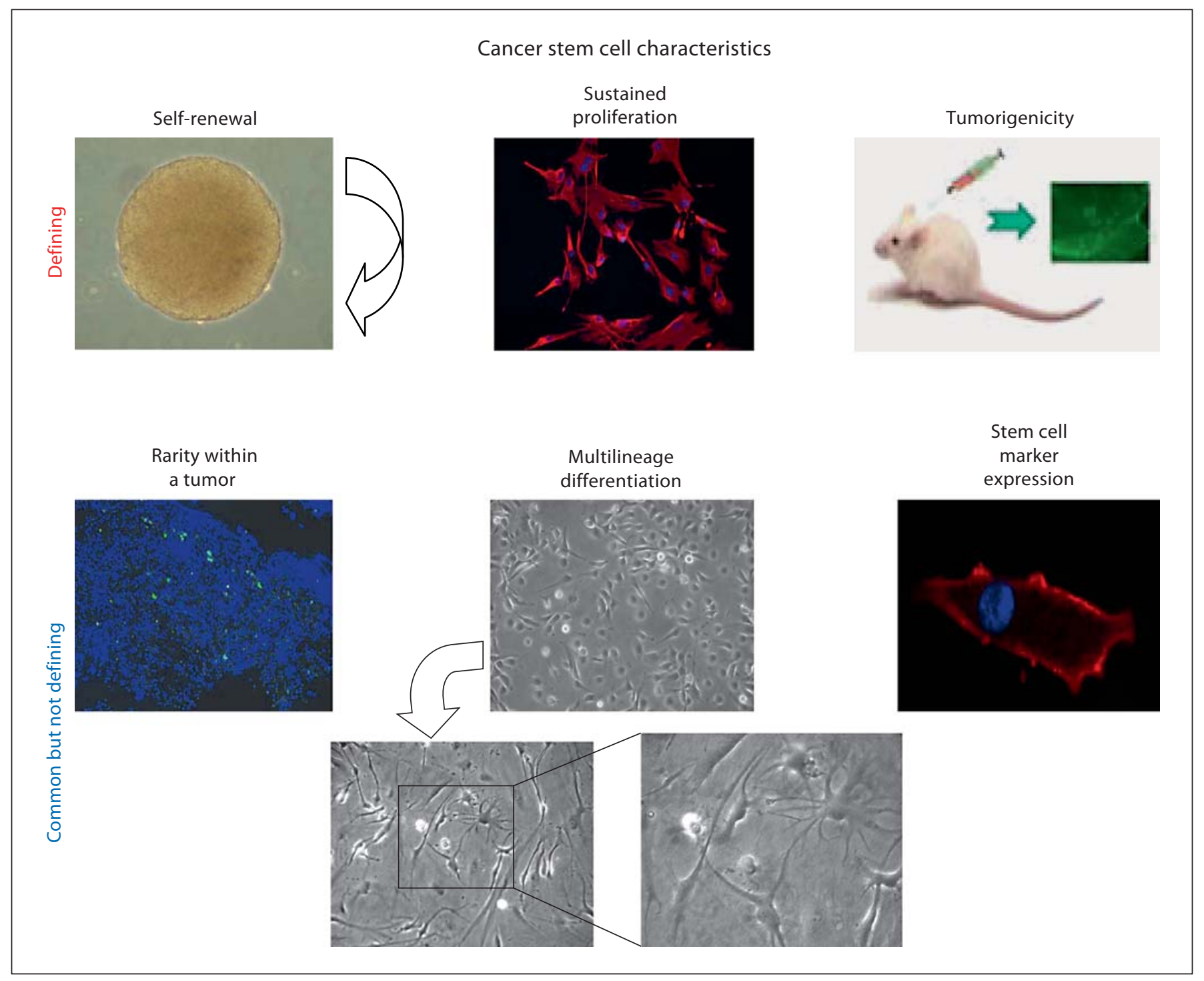

Fig. 1. Functional and phenotypical characteristics of cancer stem cells, highlighting defining features and frequently observed characteristics that are not necessarily present within this tumor cell subpopulation. Modified from Rich and Eyler [57].

WNT/ $\beta$-catenin activity [54]. Thus, it could be hypothesized that $\beta$-catenin, which controls the balance between self-renewal and differentiation, is inactivated in normal pituitary through epigenetic mechanisms that when altered may cause sustained progenitor proliferation and eventually tumor development [55]. Importantly, these data strongly support the hypothesis that genetic alterations in pituitary stem/progenitor cells may results in pituitary tumors.

In another study, it was proposed that silent corticotrope pituitary adenomas could develop in Pax7 progen- itors by conditional deletion of the retinoblastoma tumor suppressor in mice. Pax $7^{+}$cells are located in Rathke's pouch cleft and are derived from nestin ${ }^{+}$progenitor cells. Importantly, Pax $7^{+}$cells have been detected not only in mice but also in primate pituitaries and in both human functioning and silent corticotropinomas [56].

Thus, although this is still an open issue, evidence seems to propose that, as far as the pituitary is concerned, CSCs (or tumor initiating cells) might originate from genetic or epigenetic alterations in pituitary stem/progenitor cells. 
Many biological properties identified in normal stem cells were also identified in CSCs (fig. 1): a long lifespan; the capacity for self-renewal; the possibility to differentiate into all cell types present in the overall tumor population, and the strong resistance to chemotherapeutic drugs. From a biochemical point of view, CSCs express several markers typical of normal stem cells. Different from all other tumor cells, CSCs are characterized by potentially unlimited proliferation activity that allows the maintenance and expansion of the tumor, although they themselves are often slow growing. Conversely, differentiated tumor cells proliferate at a high rate, but for a limited number of cycles. Thus, tumor development relies on CSCs that represent a reservoir of tumor cells necessary to sustain the tumor mass development and an aberrant increase in self-renewal ability, in combination with the intrinsic growth potential of stem cells, and may account for much of what is considered the malignant phenotype.

Recently, the defining characteristics of CSCs and commonly identified (but non-defining) features were classified [57], as shown in figure 1.

In light of the CSC theory, the elimination of only the highly differentiated and rapidly dividing tumor cells, as resulting from the treatment with the classical chemotherapeutic agents, will likely fail to obtain successful long-term disease remission. In fact, most of the traditional cytotoxic drugs do not affect the less differentiated and slower proliferating CSCs that, surviving treatment, represent a cell reservoir able to rapidly repopulate the tumor. CSCs rarely divide and express at high levels drug transporters that can pump chemotherapy agents out of the cell. For these and other cellular properties, distinct from the rest of the tumor cell populations and detailed in the previous paragraphs, CSCs can often escape traditional cancer therapy which becomes insufficient to clear up the 'tumor-initiating cells' from the organism [58].

\section{Pituitary Adenoma Stem Cells}

Major pituitary remodeling including recurrent expansion and regression of cell populations makes the occurrence of genetic alterations and tumor formation more likely than in other tissues. Pituitary adenomas indeed are highly prevalent in humans, representing up to $15 \%$ of all diagnosed intracranial neoplasms and found in $10-25 \%$ of unselected people at autopsy [for review see 59-61]. They are typically benign tumors that only rarely metastasize [62], but can cause severe morbidity, displaying compression symptoms (including visual defects and

Adult Pituitary Stem Cells: From Pituitary

Plasticity to Adenoma Development hypopituitarism), and major endocrine syndromes, due to uncontrolled hormone secretion. To date, the molecular and cellular pathogenesis of pituitary tumors is largely unknown [63]. Although the CSC theory was mainly developed for malignant neoplasms, and CSCs were identified and isolated only from malignant tumors, the recognition of putative stem cells within the adult pituitary raised the possibility that the formation of a CSC subpopulation may also cause the formation of benign tumors, such as pituitary adenomas. Stem cell/progenitor markers were identified in hyperplastic pituitary nodules developed in nestin-GFP, Rb heterozygous mice. These tumors contained nestin-expressing cells that also express Sox 2 and Lhx3 but not pituitary hormones, and were increased 2 -fold in pituitary nodules of adult mice than in normal tissues, although the real nature of these masses was not really characterized [35].

To date, only one study proposing the possible presence of CSCs in human pituitary adenomas has been published [64]. In this study, putative CSCs, called 'pituitary adenoma stem-like cells' (PASCs), were obtained from 2 adenomas (one $\mathrm{GH}$-secreting and the other clinically non-functioning), and culturing dispersed postsurgical specimens into stem cell permissive medium (DMEM/F12, enriched with B27 supplement, bFGF and EGF). After 1 week, pituitary adenoma cells generated spheroids that grew on top of adherent cells. These spheroids were serially propagated since, after their dissociation and seeding as single cells, secondary spheres were generated [64]. PASCs within spheroids expressed nestin and $\mathrm{CD} 133$ but did not release $\mathrm{GH}$, when the single GHsecreting adenoma was analyzed. Conversely, culturing the cells in differentiation medium (containing FCS, without growth factors) several neural markers were induced ( $\beta$-tubulin III, GFAP). By quantitative RT-PCR of one PASC spheroid culture, higher expression of stem cell-associated genes (CD90, OCT-4, Musashi-1, NOTCH4, JAG2 and DLL-1) was detected than observed in the adherent cells grown under the same culture conditions. Interestingly, a rather small increase in resistance to chemotherapeutic drugs (carboplatin, etoposide) was observed comparing PASCs and adherent cells. Contrary to what was expected in CSCs, partial chemo-resistance was not dependent on increased expression of multidrug transporter genes (BCRP1, MDR1, MRP1-3) that were equally expressed in both populations, but was likely in the upregulation (one- to sixfold) of anti-apoptotic genes (BCL-2, cIAP1, NAIP and XIAP). Cells from dissociated spheroids, cultured for 2 weeks in differentiation medium (containing FCS, without growth factors), were re- 
sponsive to hypothalamic hormones as far as pituitary hormone release is concerned [64]. Regarding the cells derived from the $\mathrm{GH}$-secreting tumor analyzed, no $\mathrm{GH}$ or LH were detected before differentiation but they were detected in significant amounts after treatment in differentiation medium with GHRH and GnRH, respectively. On the other hand, undifferentiated spheroid cells released PRL and TSH in response to PRL-releasing peptide and TRH, respectively, and the secretory activity was reduced in differentiated cells. This unexpected result suggests that PASC spheroids may also include differentiated cells (secreting PRL and TSH) that could be originated by spontaneous differentiation also under non-differentiating culture conditions. Even more complex (and unexplained) is the picture regarding non-functioning adenoma cell culture in which, in response to $\mathrm{GnRH}$, undifferentiated PASCs produced LH while differentiated cells produced FSH [64].

However, although the PASC phenotype was not completely defined, the most important evidence from this study is that spheroid-derived cells $\left(1 \times 10^{4}\right.$ cells $)$, but not adherent cells $\left(1 \times 10^{5}\right)$, are able to generate tumors when implanted into the forebrain of immunodeficient NOD/ SCID mice, in vivo tumorigenicity still being the best feature to define bona fide CSCs. After 6 months, cells from the transplant tumor cells were harvested and dissociated giving rise to new spheroids that again were tumorigenic when re-injected into the brain of the NOD/SCID mice. Cell masses were immunopositive to human antigens, and some of them also expressed human GH [64].

Nevertheless, this study still left inconclusive answers and few inconsistencies: (1) more than 2 human tumors need to be analyzed to definitely prove CSC existence in pituitary adenomas, since the authors obtained these 2 cultures from a higher (although unspecified) number of tumors; (2) a high number of cells $\left(1 \times 10^{5}\right)$ were plated in the spherogenic assay, making it impossible to discriminate between real clonal spheres and nonspecific aggregates; (3) culture conditions seem to led to spontaneous differentiation making it difficult to have control over the phenotype of the cells used for in vivo tumorigenesis studies; (4) the hormonal characteristic of PASC and differentiated cells should be better defined since several unexpected and unexplained results have been described, and (5) secondary tumors showed less proliferative activity than original tumors (as far as Ki67 expression) and thus it seems that the PASC tumorigenic potential is reduced, and more than 2 serial transplants of PASC are required to prove the tumor stemness of these cultures.
Notwithstanding the existence of spheroid-forming cells in pituitary adenomas with possible self-renewal, differentiative and tumorigenic capacity was proposed prompting novel studies in support of the hypothesis that human pituitary adenomas may contain CSCs. Indeed, more recently, 2 other studies analyzing the presence of putative pituitary adenoma CSCs were reported at International Neuroendocrine Meetings [65, 66].

In surgical specimens from human pituitary adenomas (GH-, GnH- and ACTH-secreting tumors and nonfunctioning adenomas), the SP approach allowed the detection of potential CSCs in a significant proportion of total tumor cells (range 1.5-8\%) [67]. SP is now identified in most tumoral histotypes often characterized as CSCs $[68,69]$. These putative CSCs showed upregulation (as compared to the main population, MP) of multidrug transporter genes, oncogenes, and stem cell-related genes, including components of the NOTCH, WNT/ $\beta$-catenin pathways [67] that were previously involved in pituitary tumorigenesis $[53,70]$.

The second study followed the identification of the expression of another pituitary stem cell marker [71], the chemokine receptor CXCR4, in human normal pituitary and human and rat pituitary adenomas [72-75]. CXCR4 and its ligand CXCL12 are components of a large family of chemotactic cytokines (chemokines) that recently were reported to exert a much wider role in physiology and pathology than only the initially identified role in leukocyte trafficking and activity including neuroendocrine regulation [for review see 76, 77]. Briefly, CXCR4 was identified in subpopulations of human normal pituitary (about $30 \%$ of the cells) although its expression was not localized to a specific endocrine phenotype but diffuse among GH-, prolactin- and ACTH-secreting cells. Importantly, in about half of the CXCR4 ${ }^{+}$cells also its ligand (CXCL12) was expressed, suggesting a possible autocrine/paracrine mechanism of activation, and only a few CXCR $4^{+} /$hormone-negative cells, scattered throughout the anterior pituitary, were also identified [74]. However, when CXCR4 and CXCL12 expression was analyzed in a large series of human pituitary adenomas, both molecules were found highly over-expressed with all the cells in the tumoral tissues positive for CXCR4 and CXCL12. In vitro studies showed that CXCL12 activation provided a proliferation advantage to the adenoma cells [74]. CXCR4 was also expressed in several stem cell populations [78] including stem/progenitors involved in pituitary development [71], we hypothesized that putative CSCs for human pituitary adenomas may derive from CXCL12/CXCR4-expressing cells in the normal pituitary, and thus this phenotype was 
extended to all the adenoma cells [79]. In particular, these data suggested that, due to the proliferative advantage granted by CXCR4 constitutive activation, these cells could be one of the target cell populations that clonally expand during pituitary tumorigenesis. To address this issue human pituitary adenoma primary cell cultures were analyzed in vitro for some of the biological features recognized as hallmarks of CSCs (fig. 1). In particular, in vitro testing for self-renewal activity, by means of the spherogenesis assay, sustained proliferation, stem cell/ progenitor marker expression, and the differentiative potential, modifying the culture conditions from stem cellpermissive to FCS-containing medium was performed. Twelve cell cultures derived from secreting and nonfunctioning human pituitary adenoma were analyzed after fibroblast deprivation [80]. A putative subpopulation of pituitary adenoma cells with CSC features was isolated: (1) in stem cell-permissive medium they grow as pituispheres and actively proliferate up to 30 days in vitro; (2) they express stem cell markers such as nestin, CD133 and CXCR4, and (3) these cultures may undergo differentiation by replacement of medium showing changes in cell morphology, growth arrest and alternative marker expression [66].

This evidence supports the presence of CSCs within human pituitary adenomas although further formal demonstrations are still required in future studies, in particular with regard to in vivo tumorigenicity to date the definitive hallmark of CSCs.

In conclusion, although only very preliminary evidence has been reported, it is likely that pituitary adenomas may contain a driving subset of CSCs, as reported in several malignancies. Deeper studies on this cell population within the human pituitary adenoma will provide insight into the still not completely understood mechanisms of pituitary tumorigenesis and the identification of potential novel pharmacological targets for therapeutic intervention. Moreover, the identification of novel receptors endowed with proliferative activity in putative pituitary adenoma CSCs, may open the path to novel pharmacological approaches for those pituitary tumors still refractory to medical therapy. In particular, this is the case for CXCR4 antagonists [74] that are already in preclinical and clinical development [81] or novel compounds with better pharmacokinetic and toxicologic profile.

\section{Conclusions and Future Perspectives}

To date, several studies support the existence of multipotent stem/progenitor cells in the adult pituitary. Although not all the studies are completely in agreement, several features, including Sox 2 expression, SP nature, and a niche-like configuration, seem to characterize the phenotype of these cells. A necessary step ahead should be to confirm these results also in human tissues. However, although the functional relevance of stem/progenitor cells in adult pituitary cell homeostasis, potential recovery from injury, genetic endocrine deficits and tumor pathogenesis has not been formally established, the possibility of their isolation and functional analysis will provide relevant information to answer to these questions. Importantly, the characterization of pituitary stem/progenitor cells could also allow a better understanding of the biological basis of some pituitary pathologies including hypopituitarism and adenoma development. In particular, studies aimed to characterize pituitary CSCs may allow the identification of novel pharmacological targets for pituitary tumors.

\section{Acknowledgement}

This work was supported by a grant from the Italian Association for Cancer Research (2009 AIRC Program No. IG9089).

\section{References}

$>1$ Levy A: Physiological implications of pituitary trophic activity. J Endocrinol 2002;174: 147-155.

72 Levy A: Stem cells, hormones and pituitary adenomas. J Neuroendocrinol 2008;20:139140.

$>3$ Nolan LA, Kavanagh E, Lightman SL, Levy A: Anterior pituitary cell population control: basal cell turnover and the effects of adrenalectomy and dexamethasone treatment. J Neuroendocrinol 1998;10:207-215.

Adult Pituitary Stem Cells: From Pituitary

Plasticity to Adenoma Development
4 Nolan LA, Levy A: The effects of testosterone and oestrogen on gonadectomised and intact male rat anterior pituitary mitotic and apoptotic activity. J Endocrinol 2006;188:387396.

5 Drouin J, Bilodeau S, Roussel-Gervais A: Stem cells, differentiation and cell cycle control in pituitary. Front Horm Res 2010;38: $15-24$.

6 Nolan LA, Levy A: The trophic effects of oestrogen on male rat anterior pituitary lactotrophs. J Neuroendocrinol 2009;21:457-464.
7 Kominami R, Yasutaka S, Taniguchi Y, Shinohara $\mathrm{H}$ : Proliferating cells in the rat anterior pituitary during the postnatal period: immunoelectron microscopic observations using monoclonal anti-bromodeoxyuridine antibody. Histochem Cell Biol 2003;120: 223-233.

$>8$ Frawley LS, Boockfor FR: Mammosomatotropes: presence and functions in normal and neoplastic pituitary tissue. Endocr Rev 1991;12:337-355. 
$\checkmark$ Vankelecom H: Stem cells in the postnatal pituitary? Neuroendocrinology 2007;85: $110-130$.

10 McNicol AM, Carbajo-Perez E: Aspects of anterior pituitary growth, with special reference to corticotrophs. Pituitary 1999;1:257268.

$\checkmark 11$ Rizzoti K: Adult pituitary progenitors/stem cells: from in vitro characterization to in vivo function. Eur J Neurosci 2010;32:20532062.

-12 Castrique E, Fernandez-Fuente M, Le Tissier P, Herman A, Levy A: Use of a prolactin-cre/ ROSA-YFP transgenic mouse provides no evidence for lactotroph transdifferentiation after weaning, or increase in lactotroph/somatotroph proportion in lactation. J Endocrinol 2010;205:49-60.

13 Potten CS, Loeffler M: Stem cells: attributes, cycles, spirals, pitfalls and uncertainties. Lessons for and from the crypt. Development 1990;110:1001-1020.

14 Barker N, Bartfeld S, Clevers H: Tissue-resident adult stem cell populations of rapidly self-renewing organs. Cell Stem Cell 2010;7: 656-670.

15 Prockop DJ, Kota DJ, Bazhanov N, Reger RL: Evolving paradigms for repair of tissues by adult stem/progenitor cells (MSCS). J Cell Mol Med 2010;14:2190-2199.

-16 Greco V, Guo S: Compartmentalized organization: a common and required feature of stem cell niches? Development 2010;137: 1586-1594.

17 Braun KM, Prowse DM: Distinct epidermal stem cell compartments are maintained by independent niche microenvironments. Stem Cell Rev 2006;2:221-231.

18 Slack JM: Origin of stem cells in organogenesis. Science 2008;322:1498-1501.

19 Kelberman D, Rizzoti K, Lovell-Badge R, Robinson IC, Dattani MT: Genetic regulation of pituitary gland development in human and mouse. Endocr Rev 2009;30:790829.

-20 Kim M, Morshead CM: Distinct populations of forebrain neural stem and progenitor cells can be isolated using side-population analysis. J Neurosci 2003;23:10703-10709.

21 Chen J, Crabbe A, Van Duppen V, Vankelecom H: The Notch signaling system is present in the postnatal pituitary: marked expression and regulatory activity in the newly discovered side population. Mol Endocrinol 2006;20:3293-3307.

22 Chen J, Hersmus N, Van Duppen V, Caesens P, Denef C, Vankelecom H: The adult pituitary contains a cell population displaying stem/progenitor cell and early embryonic characteristics. Endocrinology 2005; 146: 3985-3998.

23 Dontu G, Abdallah WM, Foley JM, Jackson KW, Clarke MF, Kawamura MJ, Wicha MS: In vitro propagation and transcriptional profiling of human mammary stem/progenitor cells. Genes Dev 2003;17:1253-1270.
24 Seaberg RM, Smukler SR, Kieffer TJ, Enikolopov G, Asghar Z, Wheeler MB, Korbutt G, van der Kooy $D$ : Clonal identification of multipotent precursors from adult mouse pancreas that generate neural and pancreatic lineages. Nat Biotechnol 2004;22:1115-1124.

25 Chen J, Gremeaux L, Fu Q, Liekens D, Van Laere S, Vankelecom H: Pituitary progenitor cells tracked down by side population dissection. Stem Cells 2009;27:1182-1195.

-26 Fauquier T, Rizzoti K, Dattani M, LovellBadge R, Robinson IC: Sox2-expressing progenitor cells generate all of the major cell types in the adult mouse pituitary gland. Proc Natl Acad Sci USA 2008; 105:29072912.

27 Bowie EP, Ishikawa H, Shiino M, Rennels EG: An immunocytochemical study of a rat pituitary multipotential clone. J Histochem Cytochem 1978;26:94-97.

28 Shiino M, Ishikawa H, Rennels EG: In vitro and in vivo studies on cytodifferentiation of pituitary clonal cells derived from the epithelium of Rathke's pouch. Cell Tissue Res 1977; 181:473-485.

29 Otto C, tom Dieck S, Bauer K: Dipeptide uptake by adenohypophysial folliculostellate cells. Am J Physiol 1996;271:C210-C217.

30 Lepore DA, Roeszler K, Wagner J, Ross SA, Bauer K, Thomas PQ: Identification and enrichment of colony-forming cells from the adult murine pituitary. Exp Cell Res 2005; 308:166-176.

-31 Lepore DA, Thomas GP, Knight KR, Hussey AJ, Callahan T, Wagner J, Morrison WA, Thomas PQ: Survival and differentiation of pituitary colony-forming cells in vivo. Stem Cells 2007;25:1730-1736.

32 Osuna M, Yako H, Yoshida S, Sonobe Y, Inoue K, Kato T, Kato Y: S100b-expressing folliculo-stellate cells are found in Sox2-positive population in the anterior pituitary lobe and show multiple differentiation capacities in the defined culture conditions. Endocr Rev 2011;32:P1-P386.

33 Lepore DA, Jokubaitis VJ, Simmons PJ, Roeszler KN, Rossi R, Bauer K, Thomas PQ: A role for angiotensin-converting enzyme in the characterization, enrichment, and proliferation potential of adult murine pituitary colony-forming cells. Stem Cells 2006;24: 2382-2390

34 Krylyshkina O, Chen J, Mebis L, Denef C, Vankelecom H: Nestin-immunoreactive cells in rat pituitary are neither hormonal nor typical folliculo-stellate cells. Endocrinology 2005; 146:2376-2387.

35 Gleiberman AS, Michurina T, Encinas JM, Roig JL, Krasnov P, Balordi F, Fishell G, Rosenfeld MG, Enikolopov G: Genetic approaches identify adult pituitary stem cells. Proc Natl Acad Sci USA 2008; 105:63326337.

36 Weiss S, Siebzehnrubl FA, Kreutzer J, Blumcke I, Buslei R: Evidence for a progenitor cell population in the human pituitary. Clin Neuropathol 2009;28:309-318.
37 Garcia-Lavandeira M, Quereda V, Flores I, Saez C, Diaz-Rodriguez E, Japon MA, Ryan AK, Blasco MA, Dieguez C, Malumbres M, Alvarez CV: A GRFa2/Prop1/stem (GPS) cell niche in the pituitary. PLoS One 2009; 4:e4815.

38 Galichet C, Lovell-Badge R, Rizzoti K: Nestin-Cre mice are affected by hypopituitarism, which is not due to significant activity of the transgene in the pituitary gland. PLoS One 2011;5:e11443.

39 Pevny LH, Nicolis SK: Sox 2 roles in neural stem cells. Int J Biochem Cell Biol 2010;42: 421-424.

40 Alatzoglou KS, Kelberman D, Dattani MT: The role of sox proteins in normal pituitary development. J Endocrinol 2009;200:245258 .

41 Kawakami Y, Rodriguez-Leon J, Izpisua Belmonte JC: The role of TGFbetas and Sox 9 during limb chondrogenesis. Curr Opin Cell Biol 2006;18:723-729.

42 Sekido R: SRY: a transcriptional activator of mammalian testis determination. Int J Biochem Cell Biol 2010;42:417-420.

43 Castinetti F, Davis SW, Brue T, Camper SA: Pituitary stem cell update and potential implications for treating hypopituitarism. Endocr Rev 2011;32:453-471.

44 Taranova OV, Magness ST, Fagan BM, Wu Y, Surzenko N, Hutton SR, Pevny LH: Sox2 is a dose-dependent regulator of retinal neural progenitor competence. Genes Dev 2006;20: 1187-1202.

45 Ward RD, Raetzman LT, Suh H, Stone BM, Nasonkin IO, Camper SA: Role of PROP1 in pituitary gland growth. Mol Endocrinol 2005; 19:698-710.

- 46 Yoshida S, Kato T, Susa T, Cai LY, Nakayama M, Kato Y: PROP1 coexists with SOX2 and induces PIT1-commitment cells. Biochem Biophys Res Commun 2009;385:11-15.

47 Reya T, Morrison SJ, Clarke MF, Weissman IL: Stem cells, cancer, and cancer stem cells. Nature 2001;414:105-111.

48 Soltysova A, Altanerova V, Altaner C: Cancer stem cells. Neoplasma 2005;52:435-440.

49 Leder K, Holland EC, Michor F: The therapeutic implications of plasticity of the cancer stem cell phenotype. PLoS One 2010; 5:e14366.

50 Ouyang G, Wang Z, Fang X, Liu J, Yang CJ: Molecular signaling of the epithelial to mesenchymal transition in generating and maintaining cancer stem cells. Cell Mol Life Sci 2010;67:2605-2618.

51 Cerdan C, Bhatia M: Novel roles for notch, WNT and hedgehog in hematopoesis derived from human pluripotent stem cells. Int J Dev Biol 2010;54:955-963.

52 Krupkova O Jr, Loja T, Zambo I, Veselska R: Nestin expression in human tumors and tumor cell lines. Neoplasma 2010;57:291-298. 
-53 Gaston-Massuet C, Andoniadou CL, Signore M, Jayakody SA, Charolidi N, Kyeyune R, Vernay B, Jacques TS, Taketo MM, Le Tissier P, Dattani MT, Martinez-Barbera JP: Increased wingless (WNT) signaling in pituitary progenitor/stem cells gives rise to pituitary tumors in mice and humans. Proc Natl Acad Sci USA 2011;108:11482-11487.

54 Alatzoglou KS, Andoniadou CL, Kelberman D, Kim HG, Botse-Baidoo E, PedersenWhite JR, Layman LC, Martinez-Barbera JP, Dattani MT: Clinical manifestations of a novel Sox 2 mutation may result from failure to repress $\beta$-catenin-mediated target activation: Suggestion for a new mechanism for the interaction between Sox 2 and $\beta$-catenin. Endocr Rev 2011;32:P3-P758.

55 Camper SA: $\beta$-Catenin stimulates pituitary stem cells to form aggressive tumors. Proc Natl Acad Sci USA 2011;108:11303-11304.

56 Hosoyama T, Nishijo K, Garcia MM, Schaffer BS, Ohshima-Hosoyama S, Prajapati SI, Davis MD, Grant WF, Scheithauer BW, Marks DL, Rubin BP, Keller C: A postnatal Pax7 progenitor gives rise to pituitary adenomas. Genes Cancer 2010;1:388-402.

-57 Rich JN, Eyler CE: Cancer stem cells in brain tumor biology. Cold Spring Harb Symp Quant Biol 2008;73:411-420.

58 Zhou BB, Zhang H, Damelin M, Geles KG, Grindley JC, Dirks PB: Tumour-initiating cells: challenges and opportunities for anticancer drug discovery. Nat Rev Drug Discov 2009;8:806-823.

59 Melmed S: Mechanisms for pituitary tumorigenesis: the plastic pituitary. J Clin Invest 2003;112:1603-1618.

60 Melmed S: Update in pituitary disease. J Clin Endocrinol Metab 2008;93:331-338.

-61 Vandeva S, Vasilev V, Vroonen L, Naves L, Jaffrain-Rea ML, Daly AF, Zacharieva S, Beckers A: Familial pituitary adenomas. Ann Endocrinol (Paris) 2010;71:479-485.

62 Colao A, Ochoa AS, Auriemma RS, Faggiano A, Pivonello R, Lombardi G: Pituitary carcinomas. Front Horm Res 2010;38:94-108.

63 Melmed S: Pathogenesis of pituitary tumors. Nat Rev Endocrinol 2011;7:257-266.
64 Xu Q, Yuan X, Tunici P, Liu G, Fan X, Xu M, Hu J, Hwang JY, Farkas DL, Black KL, Yu JS: Isolation of tumour stem-like cells from benign tumours. Br J Cancer 2009;101:303311.

65 Gremeaux L, Fu QV, Van Duppen V, Van den broeck A, Wouters J, van Loon J, Bex M, Vankelecom H: Cancer stem cells in human pituitary adenoma: identification and characterization of a tumor 'side population' (abstract), Oncoforum. Leuven, Belgium, 2009.

66 Florio T: Recent evidence of putative human pituitary adenoma tumor stem cells (abstract S-3.3:37). 14th European NeuroEndocrine Association Congress, Lieges, Belgium, 2010.

67 Vankelecom H, Gremeaux L: Stem cells in the pituitary gland: a burgeoning field. Gen Comp Endocrinol 2010;166:478-488.

68 Kondo T, Setoguchi T, Taga T: Persistence of a small subpopulation of cancer stem-like cells in the C6 glioma cell line. Proc Natl Acad Sci USA 2004;101:781-786.

69 Hadnagy A, Gaboury L, Beaulieu R, Balicki D: SP analysis may be used to identify cancer stem cell populations. Exp Cell Res 2006;312: 3701-3710.

70 Moreno CS, Evans CO, Zhan X, Okor M, Desiderio DM, Oyesiku NM: Novel molecular signaling and classification of human clinically nonfunctional pituitary adenomas identified by gene expression profiling and proteomic analyses. Cancer Res 2005;65: 10214-10222.

71 Vankelecom H: Pituitary stem/progenitor cells: embryonic players in the adult gland? Eur J Neurosci 2010;32:2063-2081.

72 Florio T, Casagrande S, Diana F, Bajetto A, Porcile C, Zona G, Thellung S, Arena S, Pattarozzi A, Corsaro A, Spaziante R, Robello M, Schettini G: Chemokine stromal cell-derived factor $1 \alpha$ induces proliferation and growth hormone release in $\mathrm{GH} 4 \mathrm{C} 1$ rat pituitary adenoma cell line through multiple intracellular signals. Mol Pharmacol 2006;69: 539-546.

73 Barbieri F, Bajetto A, Porcile C, Pattarozzi A, Schettini G, Florio T: Role of stromal cellderived factor 1 (SDF1/CXCL12) in regulating anterior pituitary function. J Mol Endocrinol 2007;38:383-389.
74 Barbieri F, Bajetto A, Stumm R, Pattarozzi A, Porcile C, Zona G, Dorcaratto A, Ravetti JL, Minuto F, Spaziante R, Ferone D, Florio T: Overexpression of stromal cell-derived factor 1 and its receptor CXCR4 induces autocrine/paracrine cell proliferation in human pituitary adenomas. Clin Cancer Res 2008; 14:5022-5032.

75 Kim JM, Lee YH, Ku CR, Lee EJ: The cyclic pentapeptide d-Arg3fc131, a CXCR4 antagonist, induces apoptosis of somatotrope tumor and inhibits tumor growth in nude mice. Endocrinology 2011;152:536-544.

76 Bajetto A, Bonavia R, Barbero S, Florio T, Schettini G: Chemokines and their receptors in the central nervous system. Front Neuroendocrinol 2001;22:147-184.

77 Rostene W, Guyon A, Kular L, Godefroy D, Barbieri F, Bajetto A, Banisadr G, Callewaere C, Conductier G, Rovere C, Melik-Parsadaniantz S, Florio T: Chemokines and chemokine receptors: new actors in neuroendocrine regulations. Front Neuroendocrinol 2011;32:10-24.

78 Miller RJ, Banisadr G, Bhattacharyya BJ: CXCR4 signaling in the regulation of stem cell migration and development. J Neuroimmunol 2008;198:31-38.

79 Barbieri F, Bajetto A, Pattarozzi A, Gatti M, Würth R, Porcile C, Thellung S, Corsaro A, Villa V, Nizzari M, Florio T: The chemokine SDF1/CXCL12: a novel autocrine/paracrine factor involved in pituitary adenoma development. Open Neuroendocrinol J 2011;4: 64-76.

80 Florio T, Barbieri F, Spaziante R, Zona G, Hofland LJ, van Koetsveld PM, Feelders RA, Stalla GK, Theodoropoulou M, Culler MD, Dong J, Taylor JE, Moreau JP, Saveanu A, Gunz G, Dufour H, Jaquet P: Efficacy of a dopamine-somatostatin chimeric molecule, BIM-23A760, in the control of cell growth from primary cultures of human non-functioning pituitary adenomas: a multi-center study. Endocr Relat Cancer 2008;15:583596.

81 De Clercq E: The AMD3100 story: The path to the discovery of a stem cell mobilizer (Mozobil). Biochem Pharmacol 2009;77:16551664. 